\title{
Lessons learned from implementation of interferon-gamma release assay to screen for latent tuberculosis infection in a large multicenter observational cohort study in Brazil
}

Allyson G. Costa ${ }^{1,2,3,4}$, Brenda K.S. Carvalho, ${ }^{1,2}$, Mariana Araújo-Pereira $5,6,7$, Hiochelson N.S. Ibiapina ${ }^{1,2}$, Renata Spener-Gomes ${ }^{1,2}$, Alexandra B. Souza ${ }^{1,2}$, Adriano Gomes-Silva ${ }^{8}$, Alice M.S. Andrade ${ }^{5,7}$, Elisangela C. Silva ${ }^{10,11,12}$, María B. Arriaga ${ }^{5,6,7}$, Aline Benjamin ${ }^{8}$, Michael S. Rocha ${ }^{7,9}$, Adriana S.R. Moreira ${ }^{10}$, Jamile G. Oliveira ${ }^{13}$, Marina C. Figueiredo ${ }^{14}$, Megan M. Turner ${ }^{14}$, Betina Durovni ${ }^{8,13}$, Solange Cavalcante ${ }^{8,13}$, Afranio L. Kritski ${ }^{10}$, Valeria C. Rolla ${ }^{8}$, Timothy R. Sterling ${ }^{14}$, Bruno B. Andrade ${ }^{5,6,7}$, Marcelo Cordeiro-Santos ${ }^{1,2,15^{*}}$, and the RePORT Brazil Consortium

${ }^{1}$ Instituto de Pesquisa Clínica Carlos Borborema, Fundação de Medicina Tropical Doutor Heitor Vieira Dourado, Manaus, Brazil;

2Programa de Pós-Graduação em Medicina Tropical, Universidade do Estado do Amazonas, Manaus, Brazil;

${ }^{3}$ Escola de Enfermagem de Manaus, Universidade Federal do Amazonas, Manaus, Brazil;

${ }^{4}$ Diretoria de Ensino e Pesquisa, Fundação Hospitalar de Hematologia e Hemoterapia do Amazonas, Manaus, Brazil;

${ }^{5}$ Laboratório de Inflamação e Biomarcadores, Instituto Gonçalo Moniz, Fundação Oswaldo Cruz, Salvador, Brazil;

${ }^{6}$ Faculdade de Medicina, Universidade Federal da Bahia, Salvador, Brazil;

${ }^{7}$ Multinational Organization Network Sponsoring Translational and Epidemiological Research (MONSTER) Initiative, Salvador, Brazil;

${ }^{8}$ Instituto Nacional de Infectologia Evandro Chagas, Fundação Oswaldo Cruz, Rio de Janeiro, Brazil;

${ }^{9}$ Instituto Brasileiro para Investigação da Tuberculose, Fundação José Silveira, Salvador, Brazil;

${ }^{10}$ Programa Acadêmico de Tuberculose, Faculdade de Medicina, Universidade Federal do Rio de Janeiro, Rio de Janeiro, Brazil;

${ }^{11}$ Centro de Biociências e Biotecnologia, Universidade Estadual do Norte Fluminense Darcy Ribeiro, Rio de Janeiro, Brazil;

${ }^{12}$ Fundação Saúde do Estado do Rio de Janeiro, Secretaria Estadual de Saúde do Estado do Rio d Janeiro, Rio de Janeiro, Brazil;

${ }^{13}$ Secretaria Municipal de Saúde do Rio de Janeiro, Rio de Janeiro, Brazil;

${ }^{14}$ Division of Infectious Diseases, Department of Medicine, Vanderbilt University School of Medicine, Nashville, Tennessee, USA;

${ }^{15}$ Faculdade de Medicina, Universidade Nilton Lins, Manaus, Brazil. 
medRxiv preprint doi: https://doi.org/10.1101/2021.08.10.21261605; this version posted August 10, 2021. The copyright holder for this preprint (which was not certified by peer review) is the author/funder, who has granted medRxiv a license to display the preprint in perpetuity.

It is made available under a CC-BY-NC-ND 4.0 International license .

*Correspondente: Marcelo Cordeiro-Santos - marcelocordeiro@uea.edu.br.

Running Title: IGRA implementation for LTBI screening

\section{Abstract}

Background: Interferon-gamma release assay (IGRA) has emerged as a useful tool in identifying latent tuberculosis infection (LTBI). This assay can be performed through testing platforms, such as QuantiFERON-TB Gold Plus (QFT ${ }^{\circledR}$-Plus). This in vitro test has been incorporated by several guidelines worldwide and has recently been considered for the diagnosis of LTBI by the World Health Organization (WHO). The possibility of systematically implementing IGRAs such as QFT ${ }^{\circledR}$-Plus in centers that perform LTBI screening has been accelerated by the decreased availability of tuberculin skin testing (TST) in several countries. Nevertheless, the process to implement IGRA testing in routine clinical care has many gaps. Methods: The study utilized the expertise acquired by the laboratory teams of the Regional Prospective Observational Research in Tuberculosis (RePORT)-Brazil consortium during study protocol implementation of LTBI screening of TB close contacts. Results: RePORTBrazil includes clinical research sites from Brazilian cities and is the largest multicenter cohort of TB close contacts to date in the country. Operational and logistical challenges faced during IGRA implementation in all four study laboratories are described, as well as the solutions that were developed and led to the successful establishment of IGRA testing in RePORT-Brazil. Conclusions: The problems identified and resolved in this study can assist laboratories implementing IGRAs, in addition to manufacturers of IGRAs providing effective technical support. This will facilitate the implementation of IGRA testing in countries with a high TB burden, such as Brazil.

61 Keywords: Tuberculosis, IGRA, QuantiFERON-Plus, LTBI, Screening, Quality control.

\section{Importance}

The interferon-gamma release assay (IGRA) has emerged as a useful tool in identifying persons with latent tuberculosis infection (LTBI). Although the implementation of IGRAs is of utmost importance, to our knowledge, there is scarce information on identification of logistical and technical challenges of systematic screening of for LTBI on a large scale. Thus, the problems identified and resolved in this study can assist laboratories implementing IGRAs, in addition to manufacturers of IGRAs providing effective technical support. This will facilitate the implementation of IGRA testing in countries with a high TB burden, such as Brazil. 
medRxiv preprint doi: https://doi.org/10.1101/2021.08.10.21261605; this version posted August 10, 2021. The copyright holder for this preprint (which was not certified by peer review) is the author/funder, who has granted medRxiv a license to display the preprint in perpetuity.

It is made available under a CC-BY-NC-ND 4.0 International license .

\section{Introduction}

The World Health Organization (WHO) estimates that one quarter of the global population is infected with $M$. tuberculosis (Mtb) $(1,2)$. Most individuals exposed to Mtb who become infected are asymptomatic, referred to as latent tuberculosis infection (LTBI). Between 5 to $10 \%$ of individuals with LTBI, if not treated with tuberculosis preventive therapy (TPT), can progress to active tuberculosis (TB) during their lifetime $(3,4)$. Thus, diagnosis and treatment of $\mathrm{LTBI}$ is critical to reduce the incidence of active TB and control Mtb transmission.

In several countries endemic for TB, such as Brazil, screening for LTBI has traditionally utilized the tuberculin skin test (TST), which consists in the intradermal inoculation of the TBpurified protein derivative (PPD) and evaluation for cutaneous induration. However, this test has several limitations, such as false-positive reactions in persons with BCG vaccination or infection with non-tuberculosis mycobacteria, and false-negative reactions in persons with immune suppression $(5,6)$. Additional issues include the requirement for a return visit to assess the skin for induration within 48-72 hours after PPD inoculation, and the subjective interpretation of the dermal reaction (i.e., inter-reader variability) $(7,8)$. Recent scientific advances in molecular investigations allowed the isolation of Mtb-specific antigens that drive production of interferon-gamma (IFN-y) by specific T-lymphocytes, enabling the development of more specific assays based on cellular recall responses, to identify $\operatorname{LTBI}(9,10)$.

The interferon-gamma release assay (IGRA) has emerged as a useful tool in identifying persons with LTBI. This assay can be performed through two distinct testing platforms, such as the enzyme-linked immunosorbent spot (ELISPOT) assay (T-SPOT.TB) or QuantiFERON-TB Gold Plus (QFT ${ }^{\circledR}$-Plus). These in vitro tests have been incorporated into several guidelines worldwide and have recently been considered equivalent for the diagnosis of LTBI by the WHO $(9,10)$. Of note, both IGRA tests have advantages over TST in several aspects, including: (i) they do not require a follow-up visit for obtaining results, and (ii) they use in vitro stimulation of cells from the peripheral blood with Mtb-derived ESAT- 6 and CFP10 proteins, which are absent in the BCG vaccine as well as in most non-TB mycobacteria, resulting in a higher specificity (11-13). The advantages of the IGRA over the TST indicate that this immunoassay may be a reliable alternative. On the other hand, the use of IGRA results on high costs, the necessity to be carried out in sites using good clinical and laboratory practices and well-trained technical personnel and available equipment's.

The advantages of the IGRA over the TST indicate that this immunoassay may be a reliable alternative to TST. The possibility of systematically implementing IGRAs such as QFT ${ }^{\circledR}$-Plus in centers that perform LTBI screening has been accelerated by the decreased availability of TST in several countries, including Brazil (14). Implementation of QFT ${ }^{\circledR}$-Plus in TB reference centers could facilitate screening, diagnosis, and treatment of LTBI, and thereby reduce the TB burden.

Although the implementation of IGRAs is of utmost importance, to our knowledge, there is scarce information on identification of logistical and technical challenges of systematic screening of for LTBI on a large scale. The present study was designed to fill this gap and provide information that would improve the effectiveness and efficiency of IGRA-based LTBI screening. The operational and logistical challenges faced during IGRA implementation in all 
medRxiv preprint doi: https://doi.org/10.1101/2021.08.10.21261605; this version posted August 10, 2021. The copyright holder for this preprint (which was not certified by peer review) is the author/funder, who has granted medRxiv a license to display the preprint in perpetuity.

It is made available under a CC-BY-NC-ND 4.0 International license .

116 four study laboratories are also described, as well as the solutions that were developed and

117 which led to the successful establishment of IGRA testing in RePORT-Brazil.

1192 Material and Methods

$120 \quad 2.1$ Study Design and Laboratory Sites

The present investigation was an implementation study performed within a multicenter cohort study (RePORT-Brazil) between 2016 and 2019. It was conducted in five research centers located in four Brazilian cities: Fundação de Medicina Tropical Dr. Heitor Vieira Dourado (FMT-HVD) in Manaus-Amazonas, Instituto Brasileiro para Investigação da Tuberculose (IBIT) in Salvador-Bahia, Secretaria Municipal de Saúde de Duque de Caxias (SMS-DC) in Duque de Caxias-Rio de Janeiro, Instituto Nacional de Infectologia Evandro Chagas (INI) and Clínica da Família Rinaldo Delamare, Secretaria Municipal de Saúde do Rio de Janeiro (SMS-RJ) both in Rio de Janeiro-Rio de janeiro (15). The five health centers are located in 3 distinct regions of Brazil, with similar climate conditions (equatorial and tropical), temperature and humidity, showing range $19.9^{\circ} \mathrm{C}$ to $26.4^{\circ} \mathrm{C}$ and 77.2 to $85.1 \%$, respectively. $(16,17)$.

\subsection{Maintenance and Biosafety of Laboratory Sites}

Standard Operating Procedures (SOPs), Good Clinical Practice (GCP), Good Clinical Laboratory Practices (GCLP) and other trainings were carried out by the project staff prior to initiating the study. In addition, all sites provided up to date equipment maintenance certifications to ensure test quality and to minimize risks for laboratory technicians who processed biologicals daily.

\subsection{QuantiFERON-TB Gold Plus (QFT®-Plus)}

Initially QFT-TB Gold in Tube (QFT-GIT) was implemented into the laboratory routine of the RePORT-Brazil consortium, subsequently replaced by QFT ${ }^{\circledR}$-Plus. Every laboratory received training on sample collection and processing by the QIAGEN corporation (Chatsworth, CA, USA). Supplementary Figure 1 summarizes QFT ${ }^{\circledR}$-Plus steps. Briefly, venous blood for testing was collected in four tubes (Nil, TB1, TB2 and Mitogen) and incubated at $37^{\circ} \mathrm{C}$ for $20 \mathrm{~h}$. After incubation, samples were stored at $-20^{\circ} \mathrm{C}$ until the enzymelinked immunosorbent assay (ELISA) was performed within 2 weeks. IFN-y levels (international units per milliliter [IU/mL]) were quantified with a 4-point standard curve. QFT ${ }^{\circledR}$ Plus Analysis Software was used to generate the results according to the manufacturer's recommendations (18). The software performed a quality control assessment of the assay, generated a standard curve, and provided quantitative (IU/mL) and qualitative (positive, negative, or indeterminate) results. 
medRxiv preprint doi: https://doi.org/10.1101/2021.08.10.21261605; this version posted August 10, 2021. The copyright holder for this preprint (which was not certified by peer review) is the author/funder, who has granted medRxiv a license to display the preprint in perpetuity.

It is made available under a CC-BY-NC-ND 4.0 International license .

\subsection{Laboratory data of the QFT ${ }^{\circledR}$-Plus implementation process}

Laboratory information from the $\mathrm{QFT}^{\circledR}$-Plus implementation process was evaluated by the teams from all RePORT-Brazil laboratories. Data were obtained from team training, equipment maintenance, and pre-analytical evaluations, such as: type of sample collection, place of sample collection and processing, tube identification (ID), transport quality control (types of transport, time and temperature of the samples), and presence of hemolysis, clots and volume of the samples, as well as qualitative results (number of positive, negative and indeterminate tests). All data were entered into the Research Electronic Data Capture (REDCap) platform, reviewed by data managers for quality control (QC), and subsequently approved for the study analyses.

\subsection{Descriptive and Statistical Analysis}

Descriptive analyses were performed to characterize the study labs and quality control measurements. Categorical variables were displayed as frequency and percentages and compared using a two-sided Pearson's chi-square test (Yate's correction) or the Fisher's twotailed test in $2 \times 3$ or 2x2 tables, respectively. Continuous variables were displayed as median and interquartile ranges (IQR) and tested for Gaussian distribution using the D'AgostinoPearson test. Comparisons of values between two groups of data were performed using the Mann-Whitney $U$ test. The Spearman rank correlation test was carried out to assess relationships between variables. Data analyses were performed using $R$ (version 3.6.3), using Hmisc (version 4.4.1), compare Groups (version 4.4.3), ggplot2 (version 3.3.2) and ggcorrplot (version 0.1.3) R packages. All analyses were prespecified. Differences with $p$-value $<0.05$ were considered statistically significant.

\subsection{Ethical Approval}

The study was conducted according to the principles of the Declaration of Helsinki. The RePORT-Brazil protocol was approved by the institutional review boards at each study site and at Vanderbilt University Medical Center. In additional, the present study was submitted to and approved by the Ethical Committee at Instituto de Pesquisa Clínica Evandro Chagas, Fundação Oswaldo Cruz (FIOCRUZ), under the protocol registration number \#688.067, Secretaria Municipal de Saude do Rio de Janeiro (SMS/RJ), under the protocol registration number \#740.554, Hospital Universitario Clementino Fraga Filho, under the protocol registration number \#852.519, Maternidade Climério de Oliveira (MCO), Universidade Federal do Bahia (UFBA), under the protocol registration number \#723.168 and Fundação de Medicina Tropical Dr. Heitor Vieira Dourado (FMT-HVD), under the protocol registration number \#807.595. The patients, parents or legal guardians read and signed the informed consent form prior to inclusion of the patients in the study. The study fulfills the principles of the Helsinki declaration and the 466/2012 resolution of the Brazilian National Health Council for research involving human participants.

\section{$3 \quad$ Results}


medRxiv preprint doi: https://doi.org/10.1101/2021.08.10.21261605; this version posted August 10, 2021. The copyright holder for this preprint (which was not certified by peer review) is the author/funder, who has granted medRxiv a license to display the preprint in perpetuity.

It is made available under a CC-BY-NC-ND 4.0 International license .

\subsection{Interferon-gamma release assay implementation}

The IGRA/QFT ${ }^{\circledR}$-Plus implementation process started with the checklist provided by QIAGEN Corp. The four laboratories proceeded with the acquisition of equipment (micropipettes, $37^{\circ} \mathrm{C}$ incubator, centrifuge, refrigerator, freezer $-20^{\circ} \mathrm{C}$, microplate washer, microplate reader and computer), reagents (ultrapure $\mathrm{dH}_{2} \mathrm{O}$ and cleaning solutions), consumables (tips, microtubes and solution reservoir), QFT ${ }^{\circledR}$-Plus Tube kit and QFT $^{\circledR}$-Plus ELISA kit. Subsequently, laboratory technicians took GCLP and were trained on the steps of collecting, transporting, incubating, and processing samples for laboratory tests. In addition, QFT $^{{ }_{-}}$Plus ELISA kit assays were performed, and a pilot test was carried out, with the objective of including improvement strategies to initiate the study protocol (Figure 1).

During the IGRA implementation process, several gaps were identified, even after following all of the recommendations of the manufacturer of the QFT ${ }^{\circledR}$-Plus assay. Initially, the laboratories identified problems related to acquisition of equipment, reagents, and consumables. The equipment had to be purchased through the sites, generating additional costs. Furthermore, the microplate washer had problems at the beginning of the ELISA assays, requiring corrective maintenance. QFT ${ }^{\circledR}$-Plus Tube kits and QFT $^{\circledR}{ }_{-}$-Plus ELISA kits were imported, which generated logistical problems regarding delivery to the sites. To resolve this problem, delivery of the QFT ${ }^{\circledR}$-Plus Tubes and ELISA kits were directed to one of the clinical sites in Rio de Janeiro, which then distributed them to the other laboratories.

\subsection{Interferon-gamma release assay under routine conditions}

The five clinical sites started recruiting patients and collecting samples under routine conditions. Prior to starting, the collecting station was organized, accounting for the environment and the tubes to be used in the $\mathrm{QFT}^{{ }^{\circledR}}$-Plus test. These tubes had to be stored between $4^{\circ} \mathrm{C}$ and $25^{\circ} \mathrm{C}$ and taken out for immediate use only. In addition, the tubes had to be collected in a specific order, following the manufacturer's recommendations, with the Nil tube being collected first, followed by the TB1, TB2 and Mitogen tubes. The tubes containing the samples went through a homogenization process that consisted of several inversions, where all the biological material had to come into contact with the inner surface of the tube (L-motion with exactly 10 inversions). Finally, $\mathrm{QFT}^{\circledR}{ }^{\circledR}$ Plus Tubes was packed in boxes with temperatures ranging from $17^{\circ} \mathrm{C}$ to $27^{\circ} \mathrm{C}$ for transfer to the processing laboratory (Figure 2).

After collection at the clinical sites, samples were transported to the four RePORTBrazil laboratories in two different settings, clustered in: Setup A: pertaining to sites 1 and 2 , characterized by performing the collection and processing of samples in the same place, with the collection room and laboratory within the same site. Thus, the study staff responsible for collecting and organizing the samples could transport the samples to the laboratory, without requiring a vehicle (bicycle, motorcycle or car) (Figure 2A); Setup B: pertaining to sites 3, 4 and 5 , characterized by performing the collection and processing of samples in distinct places, with the need for transportation to the laboratory and thus greater demand for time, organization and attention so that there was no excessive tube vibration. This setup required a vehicle (bicycle, motorcycle or car) to transport samples (Figure 2B). 
medRxiv preprint doi: https://doi.org/10.1101/2021.08.10.21261605; this version posted August 10, 2021. The copyright holder for this preprint (which was not certified by peer review) is the author/funder, who has granted medRxiv a license to display the preprint in perpetuity.

It is made available under a CC-BY-NC-ND 4.0 International license .

Upon arrival at the labs, samples had to pass a quality check regarding transport time, temperature, tube ID, volume evaluation and the presence of hemolysis or clots. Finally, the samples were processed, incubated at $37^{\circ} \mathrm{C}$ for 20 hours, aliquots prepared, and the plasma samples frozen at $-20^{\circ} \mathrm{C}$ until the $\mathrm{QFT}^{{ }^{\circledR}}$-Plus ELISA was performed.

\subsection{Interferon-gamma release assay results under routine conditions in two settings}

Figure 3 summarizes the IGRA/QFT ${ }^{\circledR}$-Plus results under routine conditions in Setup A-B (Figure 3A) and sites 1-5 (Figure 3B) during the four-year study period (2016-2019). These results were obtained after the QFT ${ }^{\circledR}$-Plus ELISA assays were performed by the teams at the sites. For this, the aliquots containing the samples were thawed and used only once. In addition to the recommendations indicated by the manufacturer, the laboratories underwent quality control with the results validated by an external laboratory. Setup B had a higher percentage of indeterminate results, mainly in the first years of implementation of QFT ${ }^{\circledR}$-Plus. In addition, the number of samples changed over time for each setup, as follows: 2016 (Setup $A=190$; Setup $B=173$ ), 2017 (Setup $A=366$; Setup $B=258$ ), 2018 (Setup $A=505$; Setup $B=471$ ), 2019 (Setup $A=570$; Setup $B=333$ ). Also note that over the years of implementation, the indeterminate percentage tended to decrease. This could be associated with the learning process of site personnel. In addition, higher undetermined results were observed in Setup A in 2018 and 2019, specifically at site 1, which could be attributed to a greater number of tests performed in this setup and site.

\subsection{Non-conformities in Interferon-gamma release assay testing}

During the $\mathrm{QFT}^{\circledR}$-Plus implementation process, several problems were detected, generating non-conformities, such as samples without an ID, transport with temperature outside the established standard (temperature deviation), sample leakage, and other issues (e.g. transport box change, coagulated samples, or a non-standard set of transport conditions). The proportion of non-conformities is shown in Figure 4.

The temperature deviation and other non-conformities were noted particularly among Setup B sites (Supplementary Table 1) compared to Setup A in all analyzed years $(p<0.001)$. These results were likely due to conditions related to the collection and transportation of samples, since Setup B required sample transport by vehicle. In addition, these gaps generated learning opportunities for the teams, which over the years of implementation, decreased the proportion of reported non-conformities. Of note, Setup B also presented significantly higher occurrences of transport box change, coagulated samples, and lack of minimum transport conditions, characterized in the table as "Others" $(p<0.001$, Supplementary Table 1).

\subsection{Temperature deviation was the main non-conformity in Interferon-gamma release assays}


medRxiv preprint doi: https://doi.org/10.1101/2021.08.10.21261605; this version posted August 10, 2021. The copyright holder for this preprint (which was not certified by peer review) is the author/funder, who has granted medRxiv a license to display the preprint in perpetuity.

It is made available under a CC-BY-NC-ND 4.0 International license .

Temperature deviation was the main non-conformity identified in our study. When the occurrence was observed over the quarters of the evaluated years, it occurred mainly in the months with the highest temperatures at the sites, such as spring and summer $\left(3^{\text {rd }}, 4^{\text {th }}\right.$ and $1^{\text {st }}$ quarter; Figure 5). There was a decrease in this non-conformity over the years of the study period.

\subsection{Dynamics of the time and temperature between collection and processing of Interferon-gamma release assay samples}

The distance between the collection site and the sample processing laboratory directly influenced the time and the temperature variation during transportation (Table 1). Setup A showed a significantly shorter time between sending and receiving the samples in all studied years $(p<0.001)$, influencing the temperature variation (delta), which was also significantly less in comparison to Setup B $(p<0.001)$.

Setup A had higher temperature at the time of specimen shipment compared to Setup $B$, but both Setups had similar temperatures at the time of specimen receipt/arrival. (Figure 6A, 6B). Although within the established standard, Setup A had a significantly higher temperature at the time of both shipment and receipt. Despite this, the temperature variation $(\Delta)$ was significantly greater in Setup B (Figure 6 C). This can also be seen when analyzing the data by site (Supplementary Figure 2).

Over the years of implementation, the variation in time between sending and receiving samples tended to decrease until 2018, then there was an increase in $\Delta$ in 2019. The decrease in time variation was possibly because study and transport became more efficient (collection, sending and processing) with the implementation of the test on the sites. Although we observed this increase in 2019, it is noteworthy that there was an increase in the number of samples analyzed that year.

Finally, a correlation analysis was performed between the $\Delta$ (variation of receiving sending) of time and temperature. In this analysis it was possible to note that the $\Delta^{\circ} \mathrm{C}$ was directly correlated with the $\Delta$ minutes $(r=0.37, p<0.001)$, and that this variation was particularly seen in Setup B (Figure 7).

\section{Discussion}

In the IGRA implementation process, gaps were identified mainly in the pre-analytical phase of the $\mathrm{QFT}^{\Theta}$-Plus assay. The training of laboratory technicians without experience in sample collection, transporting and processing, with ELISA assays, was straight-forward and the learning curve was quick, despite pre-analytical errors identified after the start of the study. Pre-analytical errors have important implications for the reproducibility and accuracy of IGRAs, indicating the need to standardize the pre-analytical steps, as shown previously (19). The sites standardized the preventive maintenance process of the equipment, to minimize problems. The delivery of the $\mathrm{QFT}^{\circledR}$-Plus Tubes and ELISA kits were directed to one of the clinical sites, which then distributed them to the other laboratories, mitigating import and logistic issues. The steps of collection, transport and processing of the samples started to be 
medRxiv preprint doi: https://doi.org/10.1101/2021.08.10.21261605; this version posted August 10, 2021. The copyright holder for this preprint (which was not certified by peer review) is the author/funder, who has granted medRxiv a license to display the preprint in perpetuity.

It is made available under a CC-BY-NC-ND 4.0 International license.

316

317

318

319

320

321

322

323

324

325

326

327

328

329

330

331

332

333

334

335

336

337

338

339

340

341

342

343

344

345

346

347

348

349

350

351

352

353

354

355

356

357

358

359

monitored via Case Report Forms (CRFs). The lessons learned at this stage were important to create mechanisms for tracking non-conformities, It is noteworthy that the use of CRFs is indicated for monitoring non-conformities in clinical trials, however, they can also be used in routine laboratory conditions (20).

The sample collection, transport, and processing settings (Setup A and B) in the study influenced the results of the QFT ${ }^{\circledR}$-Plus. Setup B had a higher percentage of indeterminate and positive results, probably due to the longer time between the collection and processing of the samples, in addition to other variables evaluated here (e.g., temperature of transport, ID of the tubes, and packaging of the samples). It is important to ensure that, in the analytical phase, the laboratory technicians involved in these steps are comfortable with performing $\mathrm{QFT}^{\circledR}$-Plus, including simple tasks such as controlling the temperature of the shipping boxes, identifying non-conformities, minimizing errors, and identifying problems in the results generated. It is recommended to include in the $\mathrm{QFT}^{{ }^{\circledR}}{ }_{-}$Plus implementation planning a period of adaptation and short retraining, directed at the critical stages of sample collection, transport and processing, with the aim of gradually minimizing or eliminating non-conformities and preanalytical errors. This learning can assist in the quality control of test results and performance, since the reproducibility of IGRA can be influenced by these factors (21).

Biological samples can have different performance or results with respect to the quantity of analytes used and based on this, we must seek the identification of points that cause variation of test results. The laboratory routine can have different components that can cause variability in results, such as different processing rates, variation in processing rates throughout the month, and variation of factors related to the environment (such as temperature) throughout the year (22).

The reproducibility of the test results depends directly on the training of the team, since variation in the "operator" for the collection, homogenization and performance of the test can impact the result. Therefore, the standardization of quality control in the clinical and laboratory spheres is essential so that there are no significant effects on the result. In addition, structural variations between different laboratories can influence the proportion of indeterminate results $(21,23)$.

With regard to immunological molecules that can be released and consumed quickly (in vitro), delays in the start of the incubation of study samples can interfere in the quantification of IFN-y levels, leading to a decrease of up to $0.24 \mathrm{IU} / \mathrm{mL}$ after 6 hours $(19,21)$. Different incubation times, without a specific pattern, can possibly influence test results. Therefore, it is important to follow the manufacturer's guidelines $(21,23)$. The required quantity of final volume of biological sample must always be used, and it is not possible to use volumes smaller or larger than that recommended for the test. Due to the amount of "biological stimulus" available per tube, the amount of IFN- $\gamma$ released at the end of the test may be affected by variation in the sample volume used $(21,24,25)$.

The expansion of the use of IGRAs, such as QFT ${ }^{\circledR}$-Plus, must be well planned, with negotiations with the manufacturer regarding the logistics of delivery of the kits in areas with difficult access. In addition, the sample collection, transport, and processing settings must be evaluated, with the aim of mitigating errors that may interfere with the test results. Training of laboratory technicians is extremely important, and regular training develops a sense of responsibility towards reporting non-conformities and maintaining data quality after initial 
medRxiv preprint doi: https://doi.org/10.1101/2021.08.10.21261605; this version posted August 10, 2021. The copyright holder for this preprint (which was not certified by peer review) is the author/funder, who has granted medRxiv a license to display the preprint in perpetuity.

It is made available under a CC-BY-NC-ND 4.0 International license .

360

361

362

363

364

365

366

367

368

369

370

371

372

373

374

375

376

377

378

379

380

381

382

383

384

385

386

387

388

389

390

391

392

393

394

395

implementation. Finally, we believe that some of the problems identified in this study can assist laboratories wishing to implement IGRAs, in addition to manufacturers of IGRAs providing effective technical support. These findings may facilitate the implementation of IGRA testing in countries with a high TB burden, such as Brazil.

\section{Conflict of Interest}

The authors declare that the research was conducted in the absence of any commercial or financial relationships that could be construed as a potential conflict of interest.

\section{Author Contributions}

AGC and MCS established the initial conception and wrote this manuscript. AGC, BKSC, MA-P, HNSI, RS-G, ABS, AG-S, AMSA, ECS, AB, MSR, ASRM, JG and, MCF collected, analyzed, and reviewed the data. AGC, BKSC, MA-P, MMT analyzed data and designed the illustrations and tables. MCF, BD, SC, ALK, VCR, TRS, BBA, MCS supervised the project development, interpreted the data, and reviewed this manuscript. All authors read, discussed the general outline of the article together and approved the final manuscript.

\section{Funding}

The study was supported by the Intramural Research Program of the Fundação Oswaldo Cruz (B.B.A.), Intramural Research Program of the Fundação José Silveira (B.B.A., M.S.R., B.M.F.N.), Departamento de Ciência e Tecnologia (DECIT) - Secretaria de Ciência e Tecnologia (SCTIE) - Ministério da Saúde (MS), Brazil [25029.000507/2013-07 to V.C.R.] and the National Institutes of Allergy and Infectious Diseases [U01-Al069923 to TRS, ABS, GA, BMFN, ATLQ, MCF, MSR, AB, ASRM, JGO, VCR, BD, JRLS,ALK, SC, TRS, BBA, and MCS]. MAP received a fellowship from Coordenação de Aperfeiçoamento de Pessoal de Nível Superior (Finance code: 001). B.B.A, V.C.R. and A.K. are senior investigators whereas A.B.S. is a PhD fellow from the Conselho Nacional de Desenvolvimento Científico e Tecnológico (CNPq), Brazil.

\section{Acknowledgments}

The authors thank the study participants. We also thank the teams of clinical and laboratory platforms of RePORT-Brazil. A special thanks to Elze Leite (FIOCRUZ, Salvador, Brazil), Eduardo Gama (FIOCRUZ, Rio de Janeiro, Brazil), Elcimar Junior (FMT-HVD, Manaus, Brazil), and Hilary Vansell (VUMC, Nashville, USA) for administrative and logistical support. 
medRxiv preprint doi: https://doi.org/10.1101/2021.08.10.21261605; this version posted August 10, 2021. The copyright holder for this preprint (which was not certified by peer review) is the author/funder, who has granted medRxiv a license to display the preprint in perpetuity.

It is made available under a CC-BY-NC-ND 4.0 International license .

\section{Data Availability Statement}

The original contributions presented in the study are included in the article/supplementary material, further inquiries can be author/s.

\section{Contributors: Participating Investigators in RePORT Brazil Consortium}

The RePORT Brazil Consortium consists of 12 partner institutions from Brazil represented by the following members: Amanda Araújo da Costa (A.A. Costa), Instituto de Pesquisa Clínica Carlos Borborema, Fundação de Medicina Tropical Doutor Heitor Vieira Dourado, Manaus, Brazil; André Luiz Bezerra (A.L. Bezerra), Faculdade de Medicina, Universidade Federal do Rio de Janeiro, Rio de Janeiro, Brazil; Anna Cristina Calçada Carvalho (A.C.C Carvalho), Faculdade de Medicina, Universidade Federal do Rio de Janeiro, Rio de Janeiro, Brazil, Laboratório de Inovações em Terapias, Ensino e Bioprodutos,

409

410

411

412

413

414

415

416

417

418

419 Fundação Oswaldo Cruz, Rio de Janeiro, Brazil; Anna Karla Silveira (A.K. Silveira), Faculdade de Medicina, Universidade Federal do Rio de Janeiro, Rio de Janeiro, Brazil; Betânia M. F. Nogueira (B.M.F. Nogueira), Instituto Brasileiro para Investigação da Tuberculose, Fundação José Silveira, Salvador, Brazil, Multinational Organization Network Sponsoring Translational and Epidemiological Research (MONSTER) Initiative, Salvador, Brazil, Faculdade de Medicina, Universidade Federal da Bahia, Salvador, Brazil; Bruna da Costa Oliveira Lima (B.C.O. Lima), Instituto de Pesquisa Clínica Carlos Borborema, Fundação de Medicina Tropical Doutor Heitor Vieira Dourado, Manaus, Brazil; Bruna Pires de Loiola (B.P. Loiola), Instituto de Pesquisa Clínica Carlos Borborema, Fundação de Medicina Tropical Doutor Heitor Vieira Dourado, Manaus, Brazil; Carolina Arana Schmaltz Stanis (C.A. Schmaltz), Instituto Nacional de Infectologia Evandro Chagas, Fundação Oswaldo Cruz, Rio de Janeiro, Brazil; Eline Naiane de Freitas Medeiros (E.N.F. Medeiros), Instituto de Pesquisa Clínica Carlos Borborema, Fundação de Medicina Tropical Doutor Heitor Vieira Dourado, Manaus, Brazil; Francine Peixoto Ignácio (F.P. Ignácio), Instituto Nacional de Infectologia Evandro Chagas, Fundação Oswaldo Cruz, Rio de Janeiro, Brazil; Hayna Malta Santos (H.M. Santos), Faculdade de Medicina, Universidade Federal da Bahia, Salvador, Brazil, Laboratório de Inflamação e Biomarcadores, Instituto Gonçalo Moniz, Fundação Oswaldo Cruz, Salvador, Brazil; Jéssica Rebouças Silva (J.R. Silva), Faculdade de Medicina, Universidade Federal da Bahia, Salvador, Brazil, Laboratório de Inflamação e Biomarcadores, Instituto Gonçalo Moniz, Fundação Oswaldo Cruz, Salvador, Brazil; João Marine Neto (J.M. Neto), Secretaria Municipal de Saúde do Rio de Janeiro - SMS-RJ - Rio de Janeiro, Brazil, Hospital Federal do Andaraí - Ministério da Saúde, Brazil; Leandro Sousa Garcia (L.S. Garcia), Instituto de Pesquisa Clínica Carlos Borborema, Fundação de Medicina Tropical Doutor Heitor Vieira Dourado, Manaus, Brazil; Maria Luciana Silva-Freitas (M.L. Silva-Freitas), Laboratório Interdisciplinar de Pesquisas Médicas, Instituto Oswaldo Cruz, FIOCRUZ, Rio de Janeiro, RJ; Mayla Gabriele Miranda de Melo (M.G.M. Melo), Faculdade de Medicina, Universidade Federal do Rio de Janeiro, Rio de Janeiro, Brazil; Rosa Maria Placido-Pereira (R.S. Placido-Pereira), Laboratório Interdisciplinar de Pesquisas Médicas, Instituto Oswaldo Cruz, FIOCRUZ, Rio de Janeiro, RJ; Samyra Almeida-Da-Silveira (S. Almeida-Da-Silveira), Laboratório Interdisciplinar de Pesquisas Médicas, Instituto Oswaldo Cruz, FIOCRUZ, Rio de Janeiro, RJ; Vanessa de Souza Nascimento (V.S. Nascimento), Instituto Brasileiro para Investigação da Tuberculose, Fundação José Silveira, Salvador, 
medRxiv preprint doi: https://doi.org/10.1101/2021.08.10.21261605; this version posted August 10, 2021. The copyright holder for this preprint (which was not certified by peer review) is the author/funder, who has granted medRxiv a license to display the preprint in perpetuity.

It is made available under a CC-BY-NC-ND 4.0 International license .

441

442

443

444

445

446

447

448

449

450

451

452

453

454

455

456

457

458

459

460

461

462

463

464

465

466

467

468

469

470

471

472

473

474

475

476

477

478

479

480

Brazil; 5. Multinational Organization Network Sponsoring Translational and Epidemiological Research (MONSTER) Initiative, Salvador, Brazil, Bahiana School of Medicine and Public Health, Bahia Foundation for the Development of Sciences, Salvador, Brazil.

\section{Reference}

1. World Health Organization (WHO). 2020. Global Tuberculosis Report 2020World Health Organization. Geneva.

2. Houben RMGJ, Dodd PJ. 2016. The Global Burden of Latent Tuberculosis Infection: A Re-estimation Using Mathematical Modelling. PLOS Med 13:e1002152.

3. WHO. 2020. WHO | Global tuberculosis report 2019World Health Organization.

4. Horsburgh CR. 2004. Priorities for the Treatment of Latent Tuberculosis Infection in the United States. N Engl J Med 350:2060-2067.

5. Farhat M, Greenaway C, Pai M, Menzies D. 2006. False-positive tuberculin skin tests: what is the absolute effect of BCG and non-tuberculous mycobacteria? Int J Tuberc Lung Dis 10:1192-204.

6. Morrison J, Pai M, Hopewell PC. 2008. Tuberculosis and latent tuberculosis infection in close contacts of people with pulmonary tuberculosis in low-income and middleincome countries: a systematic review and meta-analysis. Lancet Infect Dis 8:359-68.

7. Secretaria de Vigilância em Saúde. Departamento de Vigilância das Doenças Transmissíveis. BM da S. 2014. Técnicas de Aplicação e Leitura da Prova Tuberculínica.

8. Brasil. 2019. Manual de recomendações para o Controle da Tuberculose no BrasilMinistério da Saúde.

9. Pai M, Behr M. 2016. Latent Mycobacterium tuberculosis Infection and InterferonGamma Release Assays. Microbiol Spectr https://doi.org/10.1128/microbiolspec.tbtb2-0023-2016.

10. Lalvani A, Pareek M. 2010. Interferon gamma release assays: principles and practice. Enferm Infecc Microbiol Clin.

11. Andersen P, Munk ME, Pollock JM, Doherty TM. 2000. Specific immune-based diagnosis of tuberculosis. Lancet.

12. Ferrara G, Losi M, Meacci M, Meccugni B, Piro R, Roversi P, Bergamini BM, D’Amico R, Marchegiano P, Rumpianesi F, Fabbri LM, Richeldi L. 2005. Routine hospital use of a new commercial whole blood interferon-y assay for the diagnosis of tuberculosis infection. Am J Respir Crit Care Med https://doi.org/10.1164/rccm.200502-196OC.

13. Theel ES, Hilgart H, Breen-Lyles M, McCoy K, Flury R, Breeher LE, Wilson J, Sia IG, Whitaker JA, Clain J, Aksamit TR, Escalantec P. 2018. Comparison of the QuantiFERON-TB gold plus and QuantiFERON-TB gold in-tube interferon gamma release assays in patients at risk for tuberculosis and in health care workers. J Clin Microbiol https://doi.org/10.1128/JCM.00614-18.

14. BRASIL M da S. 2018. Protocolo de vigilância da infecção latente pelo 
medRxiv preprint doi: https://doi.org/10.1101/2021.08.10.21261605; this version posted August 10, 2021. The copyright holder for this preprint (which was not certified by peer review) is the author/funder, who has granted medRxiv a license to display the preprint in perpetuity. It is made available under a CC-BY-NC-ND 4.0 International license .

Mycobacterium tuberculosis no BrasilMinistério da Saúde.

15. Arriaga MB, Amorim G, Queiroz ATL, Rodrigues MMS, Araújo-Pereira M, Nogueira BMF, Souza AB, Rocha MS, Benjamin A, Moreira ASR, de Oliveira JG, Figueiredo MC, Turner MM, Alves K, Durovni B, Lapa-e-Silva JR, Kritski AL, Cavalcante S, Rolla VC, Cordeiro-Santos M, Sterling TR, Andrade BB. 2021. Novel stepwise approach to assess representativeness of a large multicenter observational cohort of tuberculosis patients: The example of RePORT Brazil. Int $\mathrm{J}$ Infect Dis 103:110-118.

16. IBGE IB de GE. 2021. Mapa do clima no Brasil.

17. (CDI) CDI. 2021. Dados do clima no Brasil.

18. QIAGEN. QuantiFERON-TB Gold Plus (QFT-plus) ELISA package insert. Germantown, USA. 2017. Available at: https://www.quantiferon.com/wpcontent/uploads/2017/10/QFT-plus-ELISA-IFU- L1095849-R02.pdf Accessed on 08/03/2019.

19. Doberne D, Gaur RL, Banaei N. 2011. Preanalytical Delay Reduces Sensitivity of QuantiFERON-TB Gold In-Tube Assay for Detection of Latent Tuberculosis Infection. $\mathrm{J}$ Clin Microbiol 49:3061-3064.

20. Gliklich RE, Dreyer NA, Leavy MB. 2014. Registries for Evaluating Patient Outcomes: A User's Guidelnterfacing Registries with Electronic Health Records, 3rd ed. Agency for Healthcare Research and Quality.

21. Tagmouti S, Slater M, Benedetti A, Kik S V., Banaei N, Cattamanchi A, Metcalfe J, Dowdy D, Van Smit RZ, Dendukuri N, Pai M, Denkinger C. 2014. Reproducibility of interferon gamma (IFN-y) release assays a systematic review. Ann Am Thorac Soc 11:1267-1276.

22. FRASER CG. 2001. Biological variation: from principles to practice. Washington, DC.

23. Whitworth WC, Hamilton LR, Goodwin DJ, Barrera C, West KB, Racster L, Daniels LJ, Chuke SO, Campbell BH, Bohanon J, Jaffar AT, Drane W, Maserang D, Mazurek GH. 2012. Within-Subject Interlaboratory Variability of QuantiFERON-TB Gold InTube Tests. PLoS One https://doi.org/10.1371/journal.pone.0043790.

24. G. H. Mazurek , W. C. Whitworth DJG. 2012. Affect Of Blood Collection Time On Quantiferon®-Tb Gold In-Tube Test VariabilityIMMUNODIAGNOSTICS FOR LATENT TUBERCULOSIS INFECTION AND TUBERCULOSIS.

25. Gaur RL, Pai M, Banaei N. 2013. Impact of blood volume, tube shaking, and incubation time on reproducibility of Quantiferon-TB gold in-tube assay. J Clin Microbiol 51:3521-3526.

\section{Table and figures Caption}

Figure 1: Description of implementation of IGRA/QFT ${ }^{\circledR}$-Plus in the study. The first step was to check if all equipment and reagents were available and in good condition. Then, the 520 team was trained to perform the test following Good Clinical Laboratory Practices and 521 according to the manufacturer's recommendations. 
medRxiv preprint doi: https://doi.org/10.1101/2021.08.10.21261605; this version posted August 10, 2021. The copyright holder for this preprint (which was not certified by peer review) is the author/funder, who has granted medRxiv a license to display the preprint in perpetuity.

It is made available under a CC-BY-NC-ND 4.0 International license .

Figure 2: Two different conditions for IGRA/QFT ${ }^{\circledR}$-Plus sample collection and processing in the study. A) Setup A: utilized by Sites 1 and 2 and characterized by performing the collection and processing of samples in the same place, without a vehicle. B) Setup B: utilized by Sites 3, 4 and 5, characterized by performing the collection and processing of samples in distinct places, and transportation of the samples by vehicle.

Figure 3: Frequencies of IGRA/QFT ${ }^{\circledR}$-Plus results in each Setup and Site stratified by year of the study. A) The sites are grouped by Setup A (purple rectangles, site 1 and 2) and Setup B (green rectangles, site 3, 4 and 5). B) Results stratified by site.

Figure 4: Frequencies of conformities and non-conformities of samples in each Setup and Site stratified by year of the study. A) The sites are grouped by Setup A (purple rectangles, site 1 and 2) and Setup B (green rectangles, site 3, 4 and 5). B) Results stratified by site.

Figure 5: Number of occurrences of the non-conformity "Temperature deviation" in each Setup and Site stratified by year in period of study. A) The sites are grouped by Setup A (purple rectangles, site 1 and 2) and Setup B (green rectangles, site 3, 4 and 5). B) Results stratified by site. Color of circles indicates the year of non-conformity register and the size is proportional to the number of occurrences.

Figure 6: Dynamics of the temperature at the time of shipment and receipt of study samples, and the delta temperature variation over time in each Setup stratified by trimester and year during the study period. A) Average Temperature $\left({ }^{\circ} \mathrm{C}\right)$ of sending samples calculated by trimester and year in each setup. B) Average Temperature $\left({ }^{\circ} \mathrm{C}\right)$ of receiving samples calculated by trimester and year in each setup. C) The difference between receiving and sending temperature $(\Delta)$ was calculated for each trimester and year in each setup. Purple lines indicate Setup A and green lines indicate Setup B. The light green block indicates the limit accepted by the IGRA test manufacturer as acceptable for the storage and handling of the samples $\left(17-27^{\circ} \mathrm{C}\right)$.

Figure 7: Correlation between delta temperature variation and delta time variation of study. Purple dots indicate Setup A and green dots indicate Setup B.

Table 1: Time and temperature quality control measurements by year in period of study. "Setup A: contains Site 1 and 2, characterized by performing the collection and processing of samples in the same place. Setup B: contains Site 3, 4 and 5 . It is characterized by performing the collection and processing of samples in distinct place; "Data were compared between the setups using the Mann-Whitney $U$ test. Bold and italic font indicates statistical significance. $¥$ The number of samples changes overtime for each Setup, as follow: $2016(A=190 ; B=$ 173), 2017 ( $A=366 ; B=258), 2018(A=505 ; B=471), 2019(A=570 ; B=333)$. ${ }^{2} D a t a$ are shown as median and interquartile range (IQR). 
medRxiv preprint doi: https://doi.org/10.1101/2021.08.10.21261605; this version posted August 10, 2021. The copyright holder for this preprint (which was not certified by peer review) is the author/funder, who has granted medRxiv a license to display the preprint in perpetuity.

It is made available under a CC-BY-NC-ND 4.0 International license .

Table 1: Time and temperature quality control measurements by year in period of study.

\begin{tabular}{|c|c|c|c|c|}
\hline Parameters & Year & Setup $A^{*}$ & Setup B & p-value \\
\hline \multirow{4}{*}{$\begin{array}{l}\text { Time between sending vs } \\
\text { receiving, median }[I Q R]^{\varepsilon}\end{array}$} & $2016^{¥}$ & $\begin{array}{c}55.8 \\
{[20.1-75.1]}\end{array}$ & $\begin{array}{c}140.0 \\
{[102.0-176.0]}\end{array}$ & $<0.001$ \\
\hline & 2017 & $\begin{array}{c}58.7 \\
{[22.2-82.8]}\end{array}$ & $\begin{array}{c}121.0 \\
{[83.5-155.0]}\end{array}$ & $<0.001$ \\
\hline & 2018 & $\begin{array}{c}61.8 \\
{[25.1-90.1]}\end{array}$ & $\begin{array}{c}89.0 \\
{[29.0-164.0]}\end{array}$ & $<0.001$ \\
\hline & 2019 & $\begin{array}{c}49.5 \\
{[20.1-66.1]}\end{array}$ & $\begin{array}{c}135.0 \\
{[96.0-171.0]}\end{array}$ & $<0.001$ \\
\hline \multirow{4}{*}{$\begin{array}{l}\text { Temperature }{ }^{\circ} \mathrm{C} \text { (sending } \\
\text { samples), median [IQR] }\end{array}$} & 2016 & $\begin{array}{c}19.6 \\
{[18.1-21.2]}\end{array}$ & $\begin{array}{c}17.8 \\
{[16.0-19.1]}\end{array}$ & $<0.001$ \\
\hline & 2017 & $\begin{array}{c}21.9 \\
{[19.6-24.1]}\end{array}$ & $\begin{array}{c}18.0 \\
{[16.0-19.5]}\end{array}$ & $<0.001$ \\
\hline & 2018 & $\begin{array}{c}21.5 \\
{[19.3-23.8]}\end{array}$ & $\begin{array}{c}18.3 \\
{[16.8-19.8]}\end{array}$ & $<0.001$ \\
\hline & 2019 & $\begin{array}{c}20.6 \\
{[19.0-22.2]}\end{array}$ & $\begin{array}{c}18.1 \\
{[16.6-19.2]}\end{array}$ & $<0.001$ \\
\hline \multirow{4}{*}{$\begin{array}{l}\text { Temperature }{ }^{\circ} \mathrm{C} \text { (receiving } \\
\text { samples), median [IQR] }\end{array}$} & 2016 & $\begin{array}{c}20.1 \\
{[18.8-21.4]}\end{array}$ & $\begin{array}{c}19.6 \\
{[17.9-21.6]}\end{array}$ & $<0.001$ \\
\hline & 2017 & $\begin{array}{c}22.1 \\
{[20.6-24.1]}\end{array}$ & $\begin{array}{c}20.7 \\
{[19.5-22.9]}\end{array}$ & $<0.001$ \\
\hline & 2018 & $\begin{array}{c}21.9 \\
{[20.0-23.9]}\end{array}$ & $\begin{array}{c}20.4 \\
{[18.6-22.9]}\end{array}$ & $<0.001$ \\
\hline & 2019 & $\begin{array}{c}20.7 \\
{[19.5-22.1]}\end{array}$ & $\begin{array}{c}20.5 \\
{[18.9-22.6]}\end{array}$ & $<0.001$ \\
\hline \multirow{4}{*}{$\begin{array}{l}\text { Delta Temperature }{ }^{\circ} \mathrm{C} \\
\text { (receiving } x \text { sending, median } \\
\text { [IQR] }\end{array}$} & 2016 & $\begin{array}{c}0.54 \\
{[0.0-0.8]}\end{array}$ & $\begin{array}{c}1.82 \\
{[0.0-3.7]}\end{array}$ & $<0.001$ \\
\hline & 2017 & $\begin{array}{c}0.26 \\
{[0.0-0.1]}\end{array}$ & $\begin{array}{l}2.72 \\
{[1.2-4.1]}\end{array}$ & $<0.001$ \\
\hline & 2018 & $\begin{array}{c}0.37 \\
{[0.0-0.4]}\end{array}$ & $\begin{array}{c}2.06 \\
{[0.9-4.1]}\end{array}$ & $<0.001$ \\
\hline & 2019 & $\begin{array}{c}0.15 \\
{[0.0-0.2]}\end{array}$ & $\begin{array}{c}2.35 \\
{[1.1-4.3]}\end{array}$ & $<0.001$ \\
\hline
\end{tabular}

${ }^{\bar{*}}$ Setup A: contains Site 1 and 2, characterized by performing the collection and processing of samples in the same place. Setup B: contains Site 3, 4 and 5 . It is characterized by performing the collection and processing of samples in distinct place; "Data were compared between the setups using the Mann-Whitney $U$ test. Bold and italic font indicates statistical significance. ${ }^{¥}$ The number of samples changes overtime for each Setup, as follow: $2016(A=$ 190; $B=173), 2017(A=366 ; B=258), 2018(A=505 ; B=471), 2019(A=570 ; B=333) .{ }^{E}$ Data are shown as median and interquartile range (IQR). 


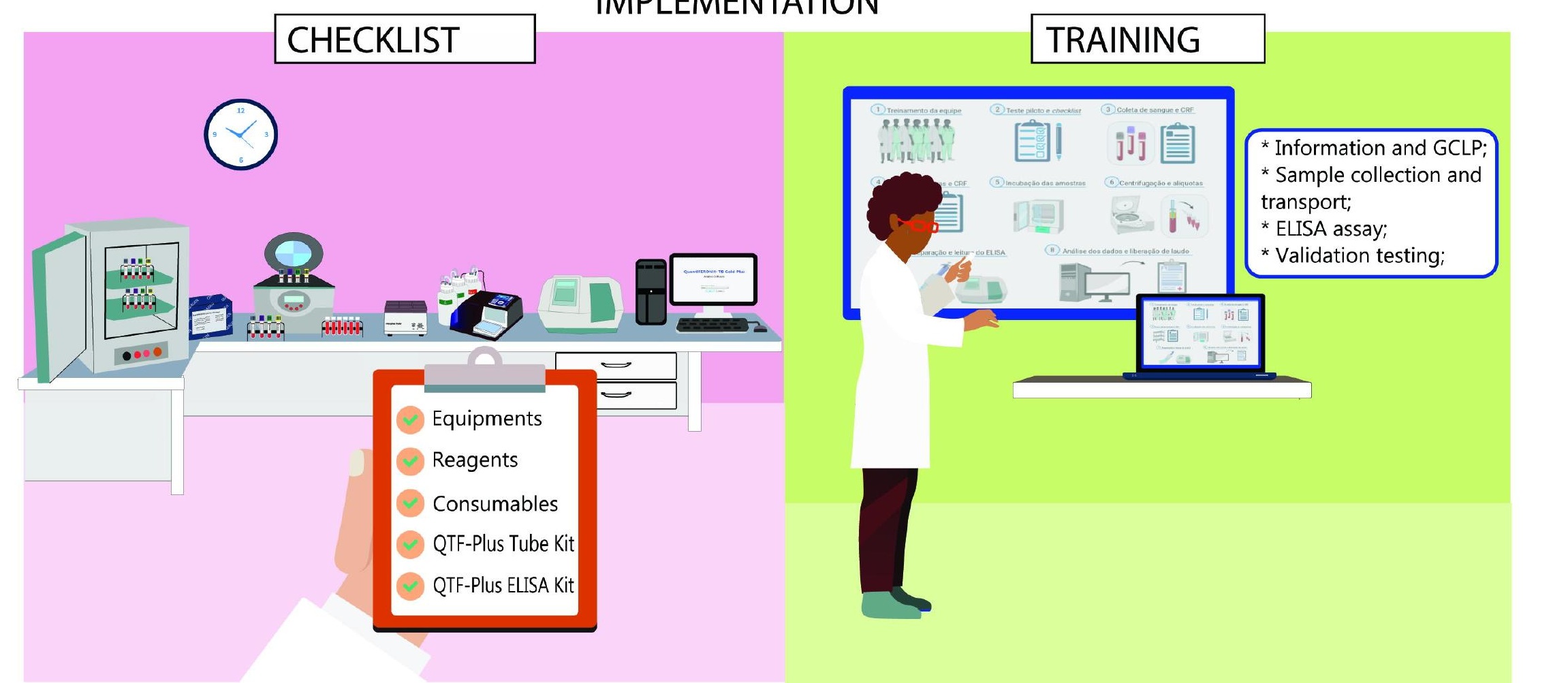




\section{Sample Collection}

* Tubes ID

* Venous puncture

* Shake tubes by inversion

\section{8}

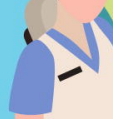

B

\section{Sample Collection}

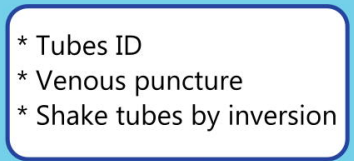

\section{Shipping}

* Temperature box $\left(17-27^{\circ} \mathrm{C}\right)$

* Transportation time (1-16 hours)

3

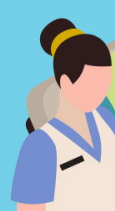

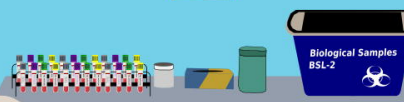
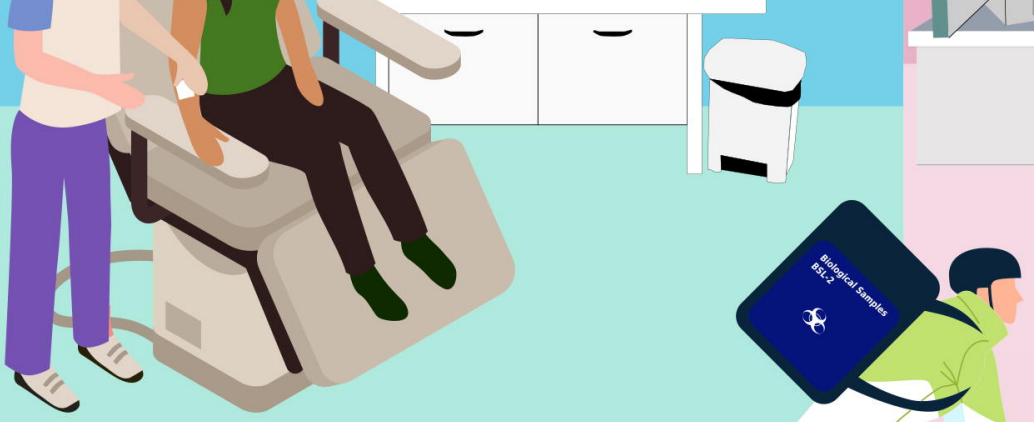

Routine

\section{Shipping}

\section{Laboratory assay}

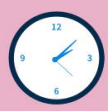

* Check samples

* Incubation time

(16-24 hours in $37^{\circ}$ )

* Sample aliquot

* ELISA assay and report

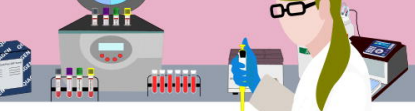
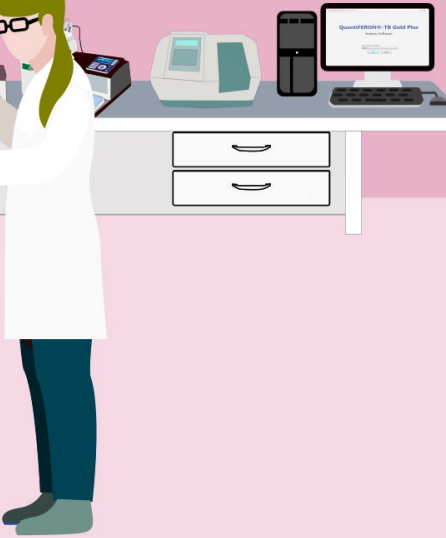

\section{Laboratory assay}

* Check samples

* Incubation time

$\left(16-24\right.$ hours in $\left.37^{\circ}\right)$

* Sample aliquot

* ELISA assay and report
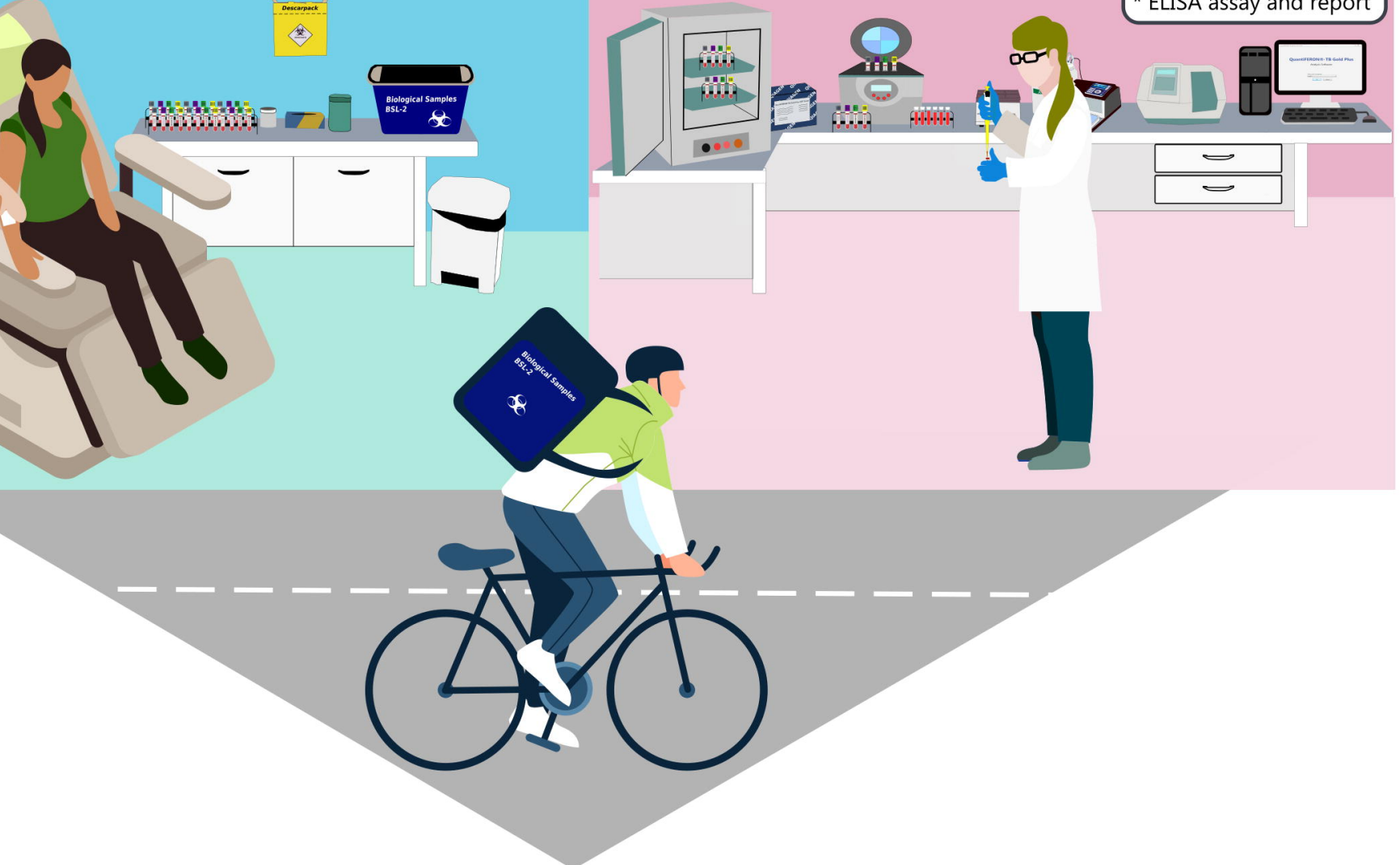
A

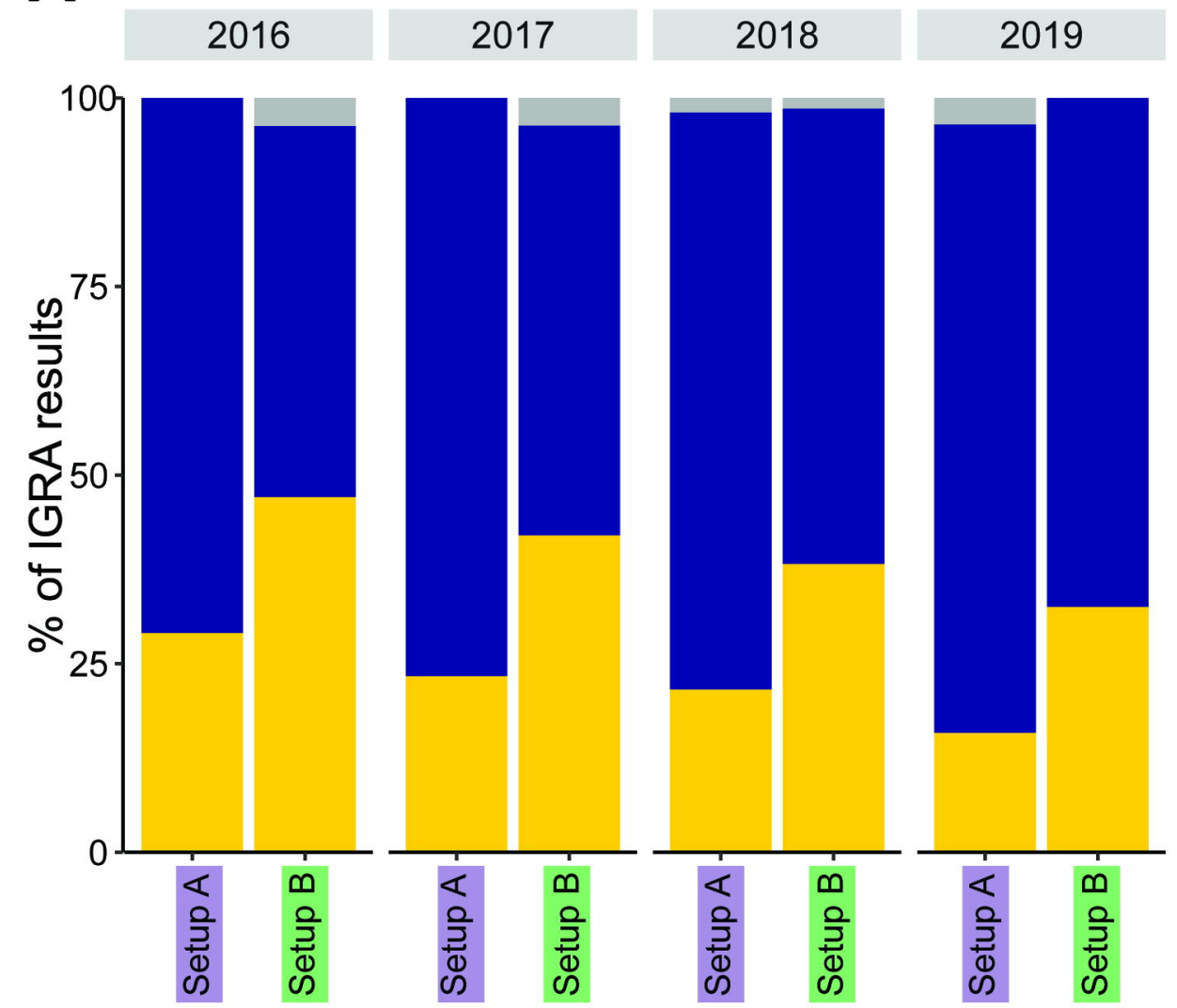

B

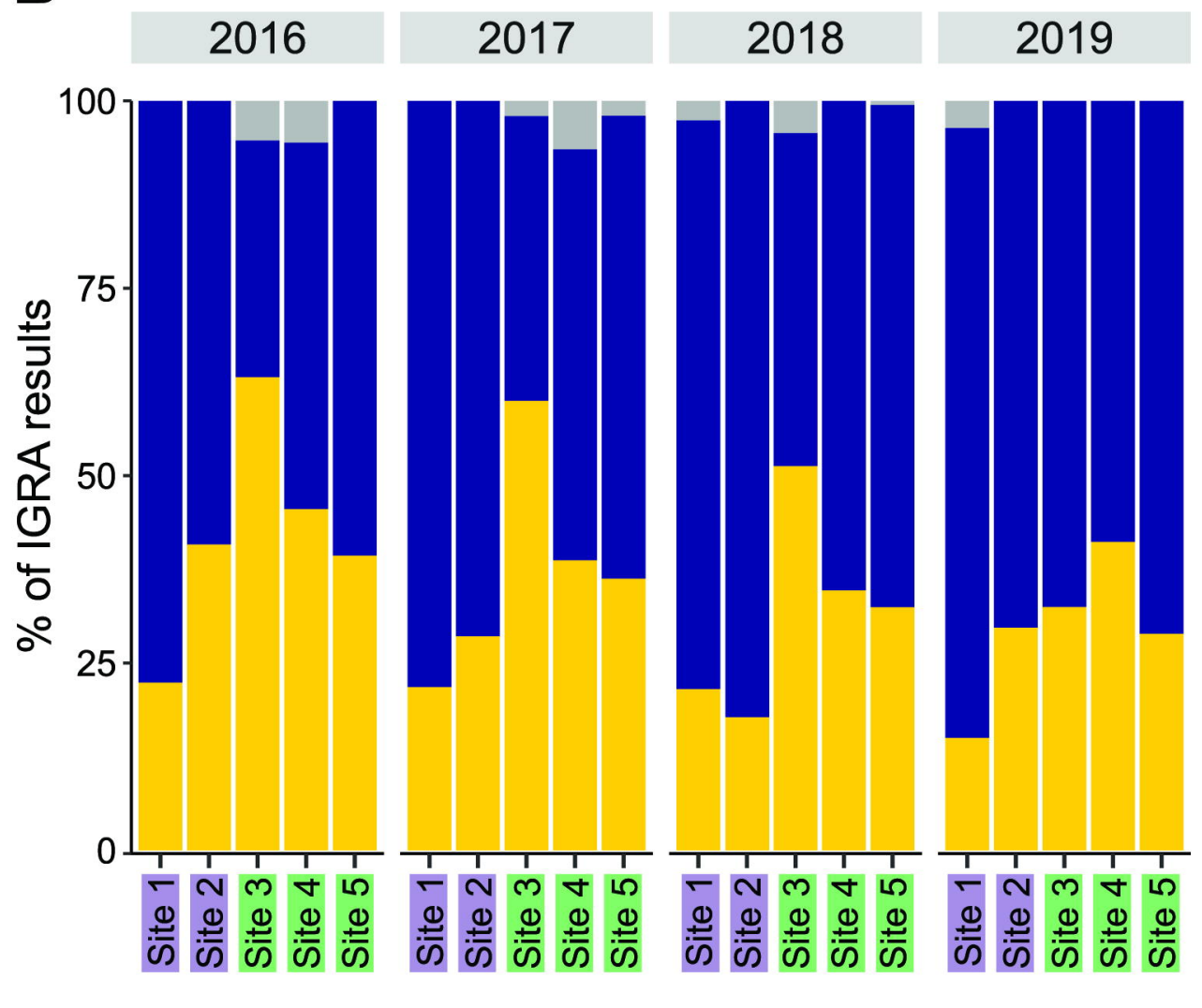


A

Setup A Setup B

B

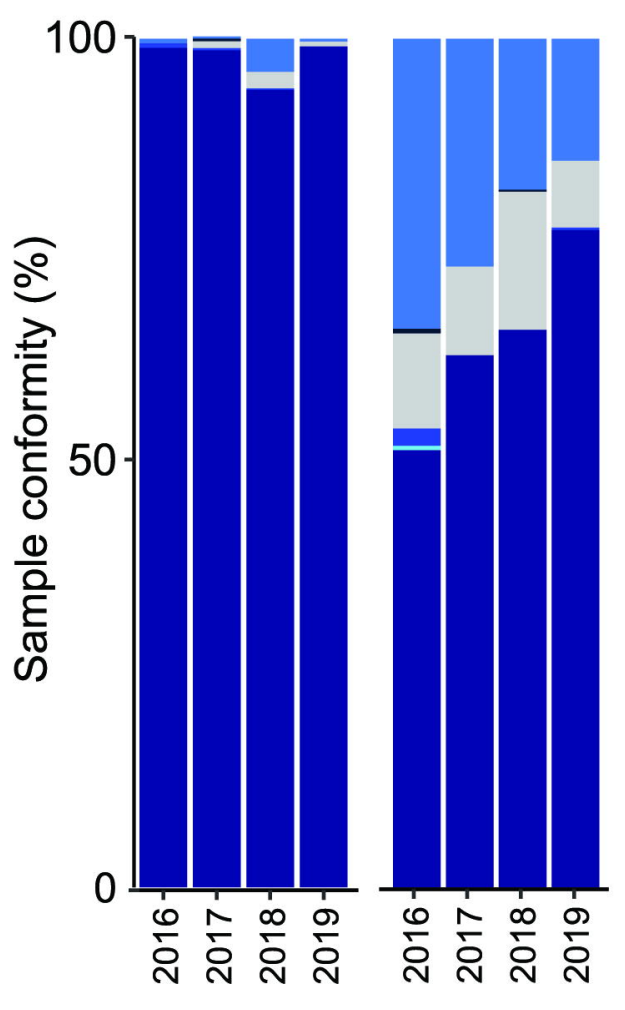

Site 1 Site 2 Site 3

Site 4

Site 5
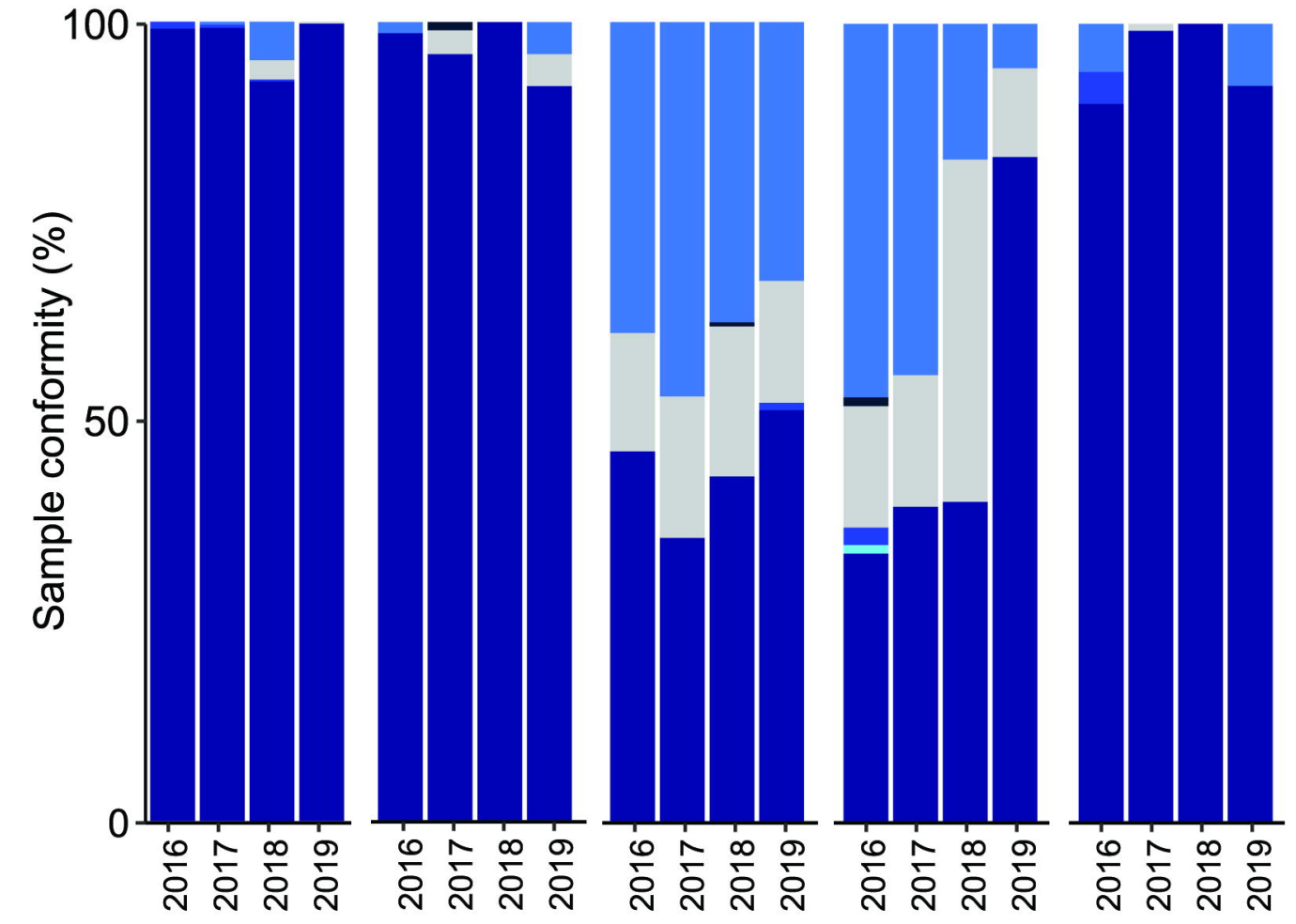


\section{A}

Setup A Setup B

B
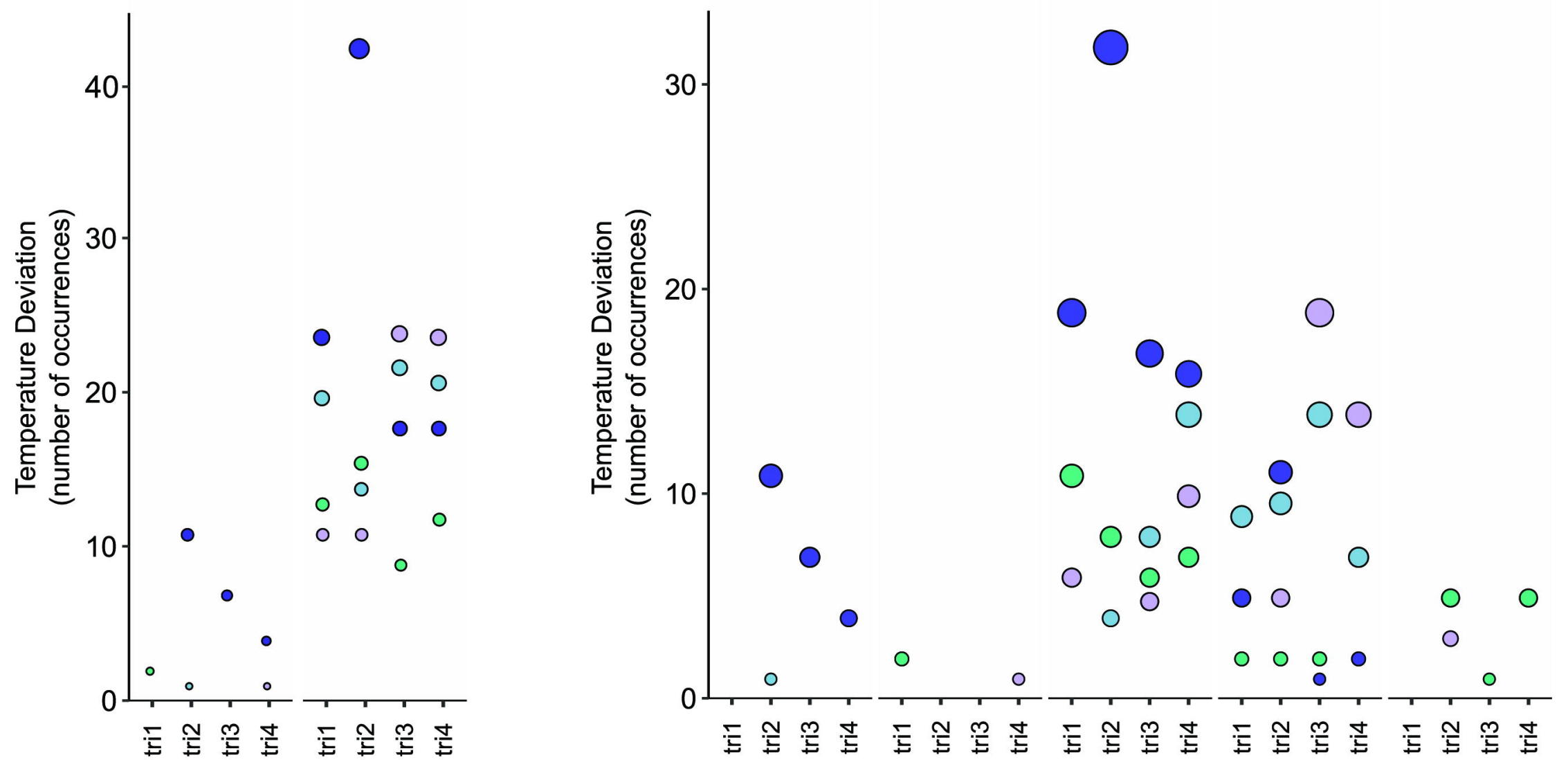
A

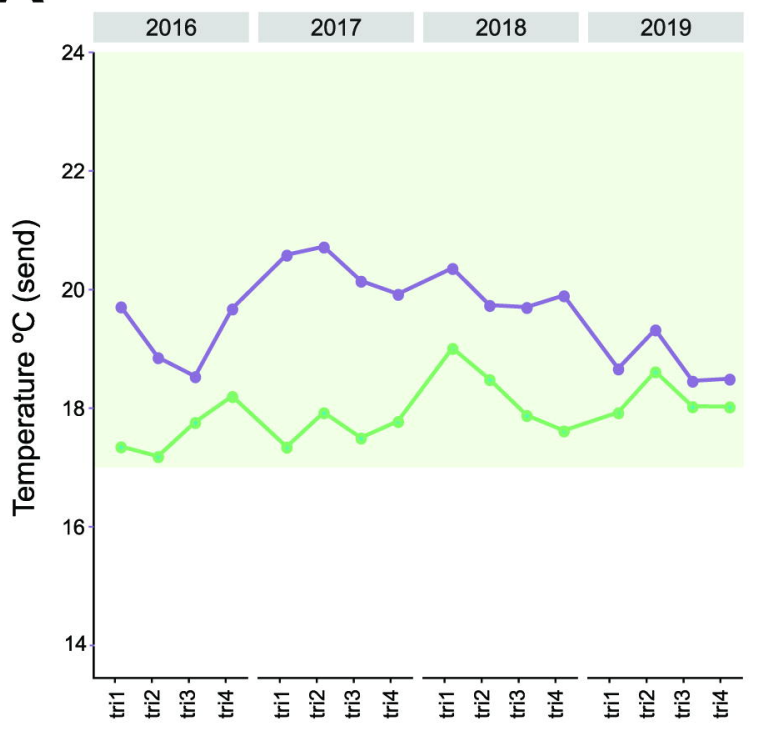

B

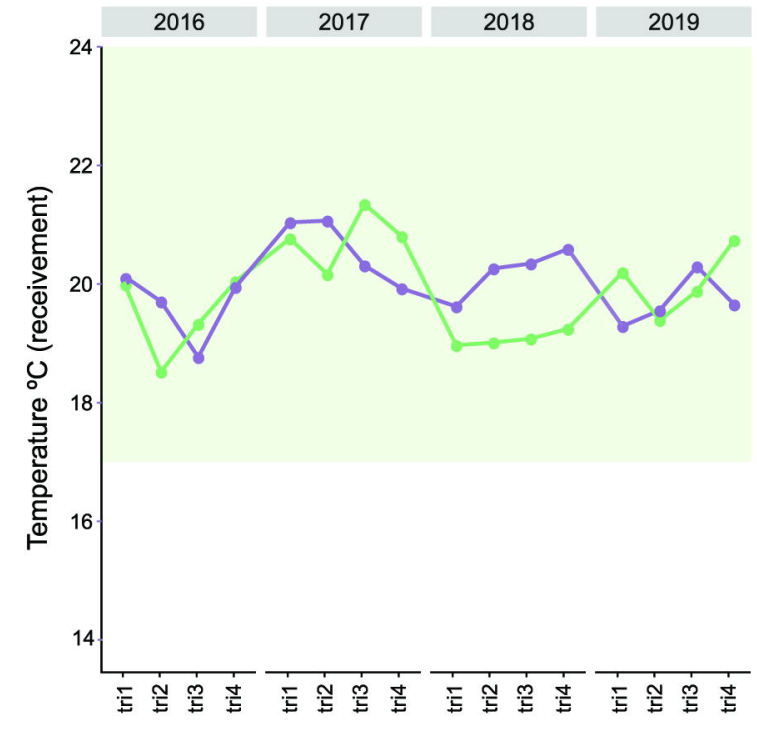

C

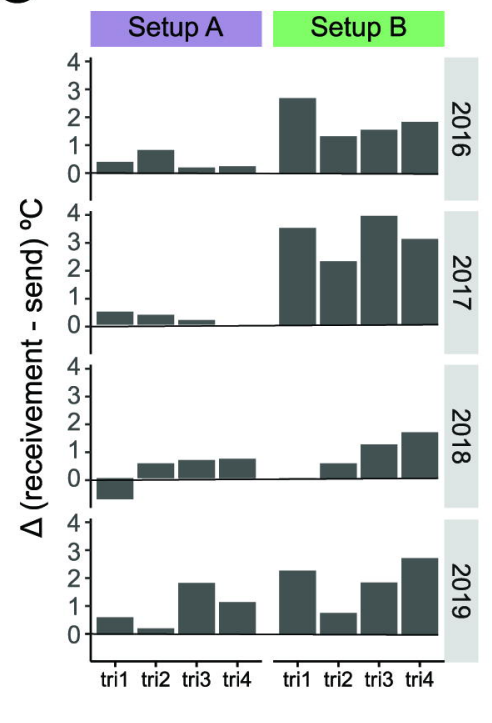




$$
R=0.37, p<0.001
$$

$0^{\circ}$

है

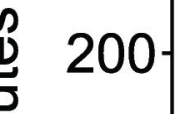

○<smiles>CCO</smiles>

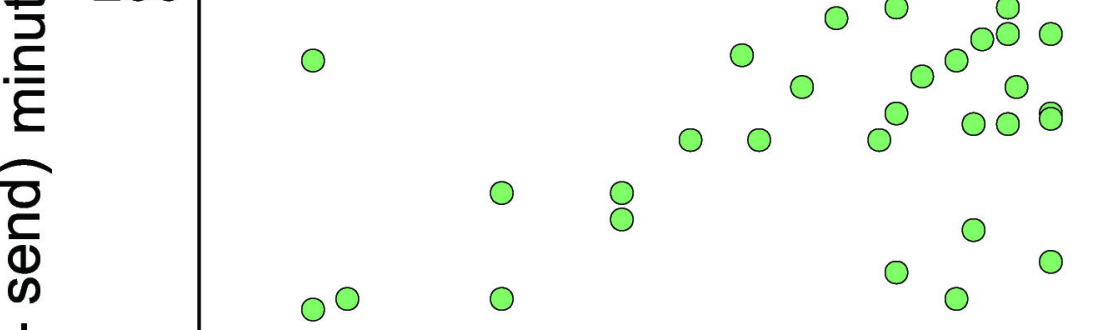

○<smiles>[O-][O-]</smiles>

O

00

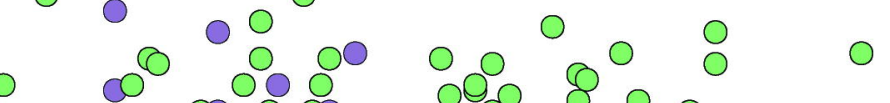

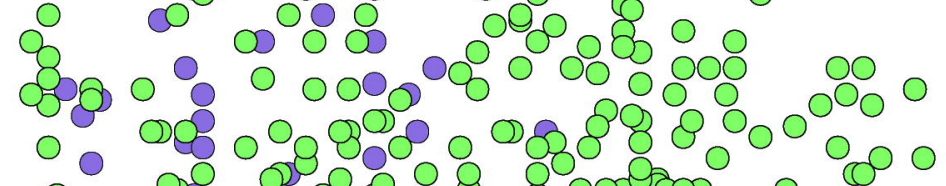

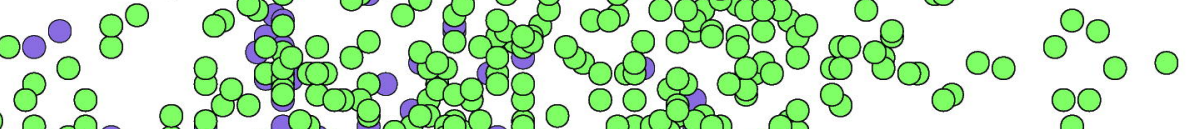

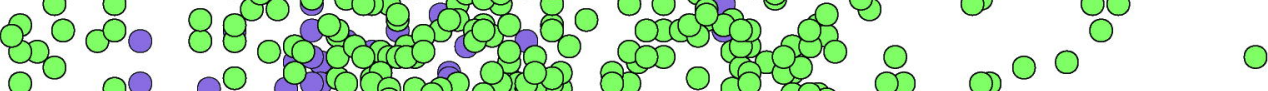

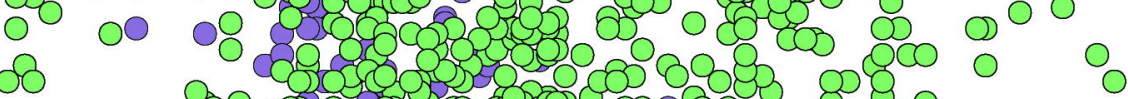

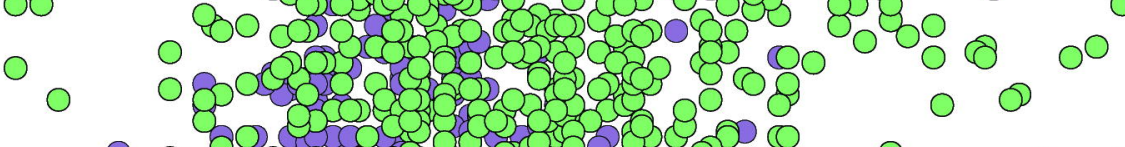

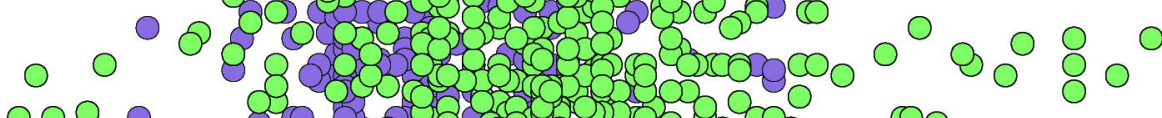

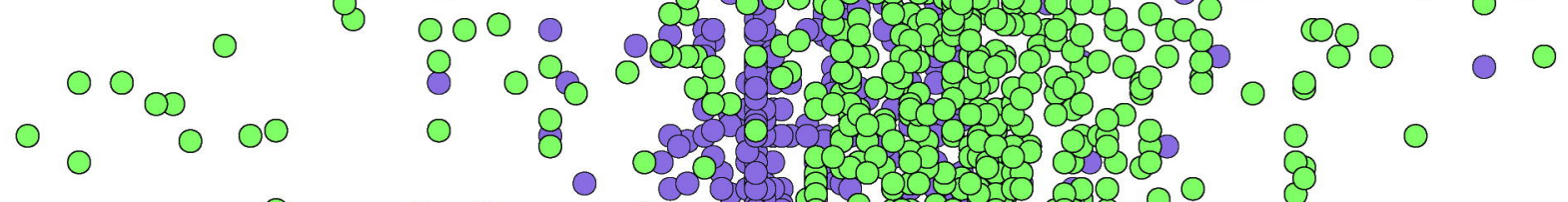

O

-

- 000003530000

0

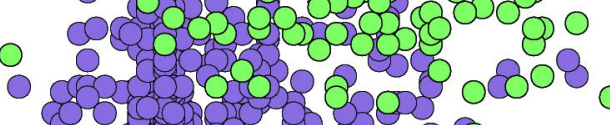

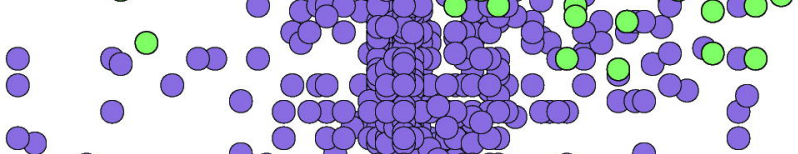

$\infty$

0

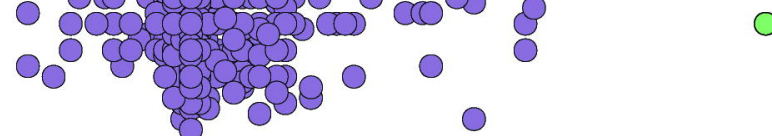

